\title{
Wittgenstein, Schopenhauer and the metaphysics of suicide
}

\section{Wittgenstein, Schopenhauer e a metafísica do suicídio}

\section{Modesto Gómez Alonso*}

University of Edinburgh, Edinburgh, United Kingdom / Universidad Pontificia de Salamanca, Salamanca, España

\section{Abstract}

In this paper, I argue that the meaning of Wittgenstein's remarks on suicide should be elucidated against the background of the transcendental picture that permeates Wittgenstein's early writings. This picture is, in its essentials, Schopenhauer's metaphysics of the Will. It is part of my purpose here to argue that the question of suicide such as Wittgenstein raises it, far from being a side issue, is internally related to problems concerning the ethical integration of Will and world, and the meaning of the world. As it will be seen, Wittgenstein manages to present a highly original view on the fundamental character of ethics that combines asceticism with an affirmative attitude to the world. Suicide would undermine ethics. As such, it stands for a nihilistic worldview.

Keywords: Asceticism. Schopenhauer. Suicide. Transcendental Ethics. Wittgenstein.

*MGA: Doutor, e-mail: mgomeza@ed.ac.uk/mgomezal@upsa.es 


\section{Resumo}

Neste artigo defendo que o significado das observações de Wittgenstein sobre o suicídio deve ser elucidado no contexto da imagem transcendental que permeia os primeiros escritos de Wittgenstein. Esta imagem é, no essencial, a metafísica da vontade de Schopenhauer. É parte do meu propósito aqui argumentar que a questão do suicídio, tal como colocada por Wittgenstein, longe de ser um problema lateral, está intimamente ligada aos problemas relativos à integração ética da vontade e do mundo e do significado do mundo. Como se procurará mostrar, Wittgenstein desenvolve uma concepção altamente original do carácter fundamental da ética que combina o ascetismo e uma atitude afirmativa em relação ao mundo. O suicídio prejudicaria a ética. Como tal, representa uma visão do mundo niilista.

Palavras-chave: Ascetismo. Ética Transcendental. Schopenhauer. Suicídio. Wittgenstein.

\section{Introduction}

It would be tempting to see Wittgenstein's remarks on suicide from a cultural and psychological perspective. Doubtless, he was not a stranger to suicide. Weininger - one of the few thinkers whose intellectual impact on him Wittgenstein explicitly acknowledges (CV, p. 16) - took his own life. Several of his brothers rushed to their voluntary deaths. Wittgenstein himself, as some of his letters to Engelmann testify, contemplated suicide. However, all these considerations do not help to clarify the meaning of his notes on the issue. Those remarks are such as to strike even the casual reader as philosophically loaded - either as the highly condensed thoughts that resulted from a metaphysical picture or as manifesting the thinker's struggle to get a firm grip on the nature of a philosophical problem. Wittgenstein was too great a philosopher not to have elucidated the problem of suicide from a perspective that, however much it touches the whole of the person, possesses an objective dimension that is irreducible to the circumstances and personality of the thinker.

Once this philosophical standpoint is taken, the question about the value and significance of Wittgenstein's views is raised. The trouble 
is that, however striking these notes may be, it is hard not to see them as thoughts that were never fully developed. It would seem, therefore, as if they were unworthy of serious philosophical consideration. It is part of my purpose here to argue that, on the contrary, the problems that Wittgenstein raised and the views that he emphatically endorsed are in keeping with his overarching transcendental conception of the metaphysical I, the fundamental character of ethics (NB, p. 79), the meaning of life, and the I as "the bearer of ethics" (NB, p. 80), as it is extensively advanced in the Notebooks 1914-1916 and tersely expressed in the Tractatus. Far from demanding further development, what Wittgenstein's views on suicide would require is an appropriate background. Such considerations naturally stemmed from the core of the metaphysical picture that permeates Wittgenstein's early writings. This picture is, in its essentials, Schopenhauer's metaphysics of the Will ${ }^{1}$.

Wittgenstein's considerations on suicide come from two sources. The first text - from the Notebooks - is dated on 10.1.1917. It puts an end to a six months sustained reflection on the nature of ethics, the conception of the I as an extensionless point (NB, p. 82), and the meaning of the world, in which Wittgenstein clearly paraphrases, amplifies and is involved in a critical/elucidatory dialogue with Schopenhauer's views on the relation between the Will and the world ${ }^{2}$. It says:

If suicide is allowed then everything is allowed. If anything is not allowed then suicide is not allowed. This throws a light on the nature of ethics, for suicide is, so to speak, the elementary sin. And when one investigates it it is like investigating mercury vapour in order to comprehend the nature of vapours. Or is even suicide in itself neither good nor evil? (NB, p. 91)

1 Among the increasing literature on Schopenhauer's impact on the Early Wittgenstein, see Janaway 1989, p. 317-342; Jacquette 2005, p. 249-261; Glock 1999, p. 422-458. Regarding the mark left by Schopenhauer on Wittgenstein's later philosophy, see Morris Engel 1969, p. 285-302 and Gómez-Alonso 2016, p. 77-108.

2 Following Wittgenstein's usage, "the world" and "the world as representation" (the phenomenal world) are synonymous. Following the standard usage in Schopenhauer's scholarship, we will distinguish between the Will with capitalization as referring to the transcendental I which is both the bearer of ethics and the bearer of phenomena, and the will to life as referring to the phenomenal drives and impulses of the psychological, individual ego. 
The second (collated) text to consider comes from two letters to Engelmann, dated respectively on 30.5.1920 and 21.6.1920. Wittgenstein was then fighting against depression. He describes his personal situation as "just like what happens when a man who can't swim has fallen into the water and flails about with his hands and feet and feels that he cannot keep his head above water" (Engelmann 1967, p. 32). Characteristically, he also makes a diagnosis of his position as resulting from his "own baseness and rottenness" (Engelmann 1967, p. 32). However, he adds the following general, thoughtful observation:

I know that to kill oneself is always a dirty thing to do. Surely one cannot will one's own destruction, and anybody who has visualized what is in practice involved in the act of suicide knows that suicide is always a rushing of one's own defences (Engelmann 1967, p. 33-35).

The first thing to say about the previous texts is that by connecting the problem of suicide with the question about the ultimate value and meaning of the world - the latter being, as Wittgenstein is eager to point, inherently related to the dichotomy between the good and the evil Will (NB, p. 73, p. 79) - , Wittgenstein explicitly conceives it as a metaphysical problem related to the "wax or wane" (NB, p. 73) of the world as a whole. Which means that Wittgenstein's objection to suicide is not moral, at least in the usual sense of the word. Thus, when saying that suicide is the elementary sin, Wittgenstein is connecting it with the fundamental nature of ethics (NB, p. 79) and so taking an ethical standpoint much higher than that taken by philosophers who discuss whether or not there are valid moral reasons against taking one's own life. Unlike Hume, Wittgenstein is not a moralist. Phenomenal considerations are simply excluded from the transcendental position that Wittgenstein adopts.

This point is further supported by the fact that, for Wittgenstein, the problem of the meaning of life is not a psychological problem, one about how to live a purposeful and fulfilled life in the world or about how to place oneself in congenial circumstances and to pursue goals consonant with one's condition. The point is that any purpose that might guide our actions as empirical egos would be determined by prudential considerations. In this sense, the prudential ego is nothing 
more than the manager of its impulses and the vehicle through which nature's ends are better acquired and expressed, as if a strong animal drive were using the ego and its monitoring control of the often chaotic and conflicting multiplicity of impulses as its channel. As such, the objects for which the ego cares provide at most a local, vulnerable and personal unity of purpose - one that fails short of the normative and integrative force that only the solution of the problem of the meaning of life would provide. Put in other words, it is meaning in an "absolute sense" (LE, p. 38) that is at stake here.

It seems, therefore, as if the questions about the possibility of transcendental and unconditional freedom, the ethical integration of Will and world, and the meaning of the world, were internally related to the question that suicide raises. As the second quoted text suggests, it is as if there were a contradiction of sorts in one's free willing to take one's own life and, correspondingly, as if suicide would always result from the $o b$ scuring of the Will that stems from animal inertia. This, in turn, raises the question of whether, suicide appearing to be an unfree act - the rushing of one's own defences - that the I can never voluntary choose, it is neither moral nor immoral. This is what the final interrogation in the Notebooks seems to consider - whether suicide is not situated, after all, beyond good and evil, lacking as such any ethical significance.

However, Wittgenstein's considerations raise more questions than they answer. On the one hand, it is hard to see why suicide should ever be seen as an act of desperation which nullifies one's rational will. It is not only that cases where, at the highest of his powers and for wellconsidered, an even philosophical reasons, the agent decides to put an end to his life are easily conceivable ${ }^{3}$, but also that, in those cases, the act stems, or so it seems, from the constant and conscious resolution on the

3 Cases of this kind are considered by Dale Jacquette in his excellent article about Schopenhauer's conception of death (Jacquette 1999, p. 293-317). Jacquette's main point is that, granted that Schopenhauer's objection to suicide cannot be coherently applied to those cases, Schopenhauer only could rely on the natural repugnance that the individual will to life feels towards death to make suicide universally objectionable. However, this would shift the problem from transcendental to phenomenal existence — something that would deprive the question of suicide of the metaphysical significance that Schopenhauer bestows to it. Note how this point is related to Wittgenstein's interrogation on whether suicide is, as such, an act that can fall under the concepts of good and evil. 
part of the agent to counterweight the power of nature's constitutive will to life, and so, to freely, voluntarily determine himself to act. One cannot say, therefore, that suicide is unfree when the agent acts contrary to drives that threaten to engulf his choice. Curiously, this is just the point made by Schopenhauer when writing that the person who takes his own life "moves us to sorrow and sympathy often mingled with a certain admiration for his courage" (Schopenhauer 1974, p. 306).

On the other hand, it is clear neither what it means to say that suicide is the elementary sin nor what Wittgenstein is asking himself by considering the opposing alternative - that it is ethically negligible. Something has been already said on this issue. However, the two alternatives being correlative, the first one has to be further developed to throw light on its own meaning, as well as on the meaning of its negation.

Here is the plan. In section 1, I will trace Schopenhauer's conception of suicide back to the "single thought" (Schopenhauer 2010, p. 5) that unifies the whole of his philosophical system. Schopenhauer's metaphysical conception provides the right background to understand his views on suicide. Since that conception is - to a large extentshared by the early Wittgenstein, it will serve the purpose of clarifying the latter's thoughts on suicide against the background of the transcendental ethics that he takes from his predecessor. We will thus follow the two philosophers up to the point where their paths part. In section 2, I will show how Wittgenstein manages to combine the ascetic perspective shared by Schopenhauer and Tolstoy with an affirmative attitude to the world that, not unlike the attitude proposed by Nietzsche, is a far cry from the world-devaluing interpretation of the ascetic ideal that Schopenhauer puts forth. The transcendental position is, thus, both the standpoint where phenomenal willing ceases and the perspective from which the "agreement with the world" (NB, p. 75) that defines a happy/good life is finally achieved. This article thus aims at contributing to the study of the unitary nature of the early Wittgenstein's transcendental ethics. What unifies it is the thought that the transcendental I is the judge of the world and the measurer of things (NB, p. 82). 


\section{Wittgenstein's Schopenhauerian Transcendentalism and the problem of suicide}

At least to a first approximation, it is not apparent how the morbid catalogue of aimless pains, tormenting boredom and illusory happiness that Schopenhauer provides to convince us that the essence of life is suffering, to the point of declaring that "the much-lamented brevity of life might be the best thing about it" (Schopenhauer 2010, p. 351), could fail to lead to a rational defence of suicide not unlike the one taken by Hume in his posthumous essay on this topic. It is true that the individual will to life naturally recoils at the prospect of one's death. However, as Schopenhauer is keen to recall, death confronts us as the definitive end of suffering. Which means, on the one hand, that even the instinctive dread of death can be outweighed by the intensity and inescapability of suffering, and, on the other, that from a rational perspective the possibility of voluntary death appears as the escape from the burdens of life and the means to liberation - not as a crime, but as a gift - . There are circumstances in which the force of nature is naturally overcome by the terrors of life. More importantly, the appeal to such force does not count as an argument within the discursive space governed by reason. It is within such space that suicide must be evaluated. And from what Schopenhauer thinks of the general character of life, it seems to stand to reason. Then, what can be wrong with suicide?

The natural place to look for an answer is Kant's Groundwork of the Metaphysics of Morals, where Schopenhauer's master considers the case of an agent who deliberates about shortening his life under circumstances where prospective suffering outweighs agreeableness (Kant 1998, p. 32-33). There Kant provides two (related) arguments against the rationality of suicide. For one thing, the decision to take one's own life would be a natural maxim that, as such, fails to become a universal law of nature, and so, to be a universal rule capable of governing agents independently of who they are, the interests by which they are motivated, and how they are situated or physically constituted. Since universality and unconditionality are the marks of rational duties, and suicide would be inherently situational, suicide cannot be 
freely, rationally chosen. It belongs, among other drives and impulses, to the domain of the empirical, natural ego.

Kant's point that suicide cannot be rationally chosen is further supported by what he describes as the contradictory nature of the would-be suicide's reasoning. This would involve a contradiction between the end in the endeavour of which the agent determines himself to take his life - the improvement of his condition - and the very means by which he will achieve such purpose - the destruction of his life and body-. Improving life by destroying life - the means-end structure that operates as the standard on the basis of which rational behaviour is made possible is, for Kant, undermined by the decision of the potential suicide.

Schopenhauer's overarching rejection of Kant's categorical imperative as the ultimate source of morality, as well as his searing remarks on Kant's argument against suicide (Schopenhauer 2009, p. 160), seem to indicate, as commentators have observed (Jacquette 1999, p. 304-305), that his objection is of a different nature. I am unimpressed by these considerations. As we shall see shortly, Kant's arguments can be easily developed so as to lead to Schopenhauer's transcendental standpoint. First, however, let us consider a further complication for accommodating the rejection of suicide into Schopenhauer's general metaphysics.

As it is well known, Schopenhauer accepted the core of Kant's transcendental idealism as it is expressed in the distinction between the phenomenon/representation/appearance and the the thing in itselft.

The trouble with this drastic distinction between the phenomenal and the noumenal aspects of the world is that it sets up a contrast between the illusory domain of the plurality of objects of representation

4 This distinction would require further and much more nuanced analysis, since the Will is for Schopenhauer not so much a transcendent thing-in-itself that exists beyond any possible experience as the noumenal and inner kernel that underlies the perceptive and empirical aspects of the world. Not unlike how contemporary power theorists conceive underlying dispositions as fundamental properties of reality that are empirically manifested under the right conditions and circumstances, Schopenhauer sees the Will as the underpinning force behind phenomena —one that, instead of being causally related to them, is manifested in them-. Thus, the metaphysical Will is the deeper aspect of the world as representation; an aspect that, though it cannot be reached through objective, representative experience, is noninferentially and immediately apprehended through the internal access of the subject to his own willing.

Rev. Filos., Aurora, Curitiba, v. 30, n. 49, p. 299-321, jan./abr. 2018 
- a domain whose contents are ordered by the forms of transcendental subjectivity: space, time and causality - and the reality of the underlying non-personal Will ${ }^{5}$. Empirical events are, as such, unreal. The individual personality of the empirical ego is, as such, illusory. Since one's inner nature is identical with the metaphysical Will, it remains unaffected either by anything that happens to one or by anything that one chooses to do. The irreality of death thus follows from the irreality of life, and the empirical existence and death of the ego is nothing else than that of "an animated nothing" (Schopenhauer 1974, p. 270) - one more fulguration of the eternal Will. The individual actions of human agents are, therefore, related to each other in the sense of being the manifestation of a single, fundamental nature. This nature is indestructible $^{6}$ at the cost of being inalterable.

The logical conclusion is that because any phenomenal deed is deprived of metaphysical and ethical significance, there is nothing wrong with suicide. Just like natural death, suicide is illusory. This would seem also to follow from Wittgenstein's Schopenhauerian thought that death "is not an event in life ... a fact in the world" (NB, p. 75), so that it seems plausible to claim that these are the considerations that constitute the background of Wittgenstein's final interrogation in NB.

Notice, besides, that Schopenhauer's account apparently fails to allow for the possibility of moral improvement, as well as for the possibility of redemption through the rejection of the will to life. Since one does not have the power to affect or to amend through one's actions one's nature, it is hard to see how one's character can undergo the radical transformation that, for Schopenhauer, is the necessary requirement of morality. Thus, Schopenhauer's system is threatened by a fundamental incoherence.

Granted that because there is no personal afterlife, suicide cannot be coherently seen as a transition from a bad to a better condition of

5 This doctrine is echoed by Wittgenstein in the Notebooks 1914-1916, where he writes that "if the Will did not exist, neither would there be that centre of the world" (NB, p. 80) and speaks of the metaphysical I as something that "is common to the whole world" and that is both "my will" and the "world-will" (NB, p. 85).

6 This is the kind of survival after death that, for Schopenhauer, one can rationally expect - the survival of the inner nature common to all phenomena, a nature that is deprived of personality and consciousness. See Schopenhauer 1974, p. 266-282. 
the conscious ego, it is still true that suicide might be a liberation from the miseries of life. But then and again, what can be wrong with suicide when it is a rationally and morally blind urge alone - the phenomenal will to life- that opposes it?

The emphatic contrast that Schopenhauer makes between the merely negative cessation of existence and the positive destruction of one's body that is involved in voluntary death (Schopenhauer 1974, p. 310 ) is interesting as a first indication of the kind of answer that he attempts to develop. It is not that self-destruction is an act of self-inflicted violence that, as such, is much more difficult to accomplish ${ }^{7}$. It is, on the contrary, the very fact that it is an action and that, as such, it is set into motion by the will of the agent what, according to Schopenhauer, throws light on the "futile and therefore foolish" (Schopenhauer 2010, p. 307) nature of suicide. The point is that it is the individual will to life itself that moves the agent to annihilate the external objectivation of the will to life - the body - , so that the will to life turns upon itself and affirms itself by means of its negation. It is therefore by love of life that one comes to voluntarily take leave of life. Far from being opposed by the instinct of self-preservation, suicide is the paradoxical result, and maybe the purest manifestation of such an instinct. Suicide involves, after all, a kind of contradiction - though it is not a self-contradiction in the reasoning of the potential suicide, as Kant saw it, but instead a contradiction of life with itself-.

However, one must not take what Schopenhauer says about the contradictory nature of suicide as sufficient to support an objection to it. After all, suicide still appears for the individual as the end of suffering and the escape from misery. The key point lies elsewhere.

It lies in the fact that the will to life turns upon the body so that the former "might remain unbroken" (Schopenhauer 2010, p. 427). The suicide can well escape from individual misery. But he does not escape from his will to life, and so, from himself. As a matter of fact, his act

As Schopenhauer is keen to insist, self-inflicted violence is not a factor that necessarily restrains the potential suicide who is weary of life. As he writes, "it is precisely because mental pain makes us insensible to physical pain, being by far the greater of the two, that suicide is very easy for someone who is in despair or is consumed by pathological depression, even if he would have found the thought shocking in earlier, happier days" (Schopenhauer 2010, p. 325-326). 
marks the irrevocable victory and, as it were, the apotheosis of the will to life, which, to remain unaltered, thwarts the abolition of the Will and the whole alteration of the human character that might result from the sanctifying nature of extreme suffering. Too weak to overcome his drives and to reach a victory over himself, the suicide "stops living precisely because he cannot stop willing" (Schopenhauer 2010, p. 426). This is why suicide is bestowed with a metaphysical and ethical significance - because it involves a decisive and irrevocable decision where what is at stake is both the very integrity of the self, which is tested, and the meaningful or meaningless character of the world that is the external aspect of the Will. Suicide prevents transcendental freedom. Far from being a phenomenal, illusory act, it touches the noumenal, essential nature of the ego. Not unlike how Wittgenstein conceives the fear of death as "the best sign of a false, i.e. a bad, life" (NB, p. 75), suicide is for Schopenhauer the manifestation of the ethical failure of the self to transcend itself and to liberate itself from the clutches of its empirical character. It is not therefore a mere event in the world. On the contrary, it is the exact point where a phenomenal and an intelligible or noumenal deed coincide so that by freely opposing to become free from the will to life, the self irrevocably plunges itself into willing - and death.

Suicide is thus metaphysical in two senses - because it is a free rejection of freedom so that the suicide is guilty of giving in to his animal urges; and because by leaving unfulfilled the ends of nature, with his act the suicide makes the world wane into nothingness, depriving it of its centre and significance. Suicide reverberates throughout the whole fabric of the universe, affecting its very structure and making it to collapse. This latter aspect leads us directly to the "single thought" that unifies Schopenhauer's system and that it is partially expressed in Wittgenstein's early reflections on ethics. First, however, let us briefly return to Kant's objection to suicide. This will help us to clarify some of the most difficult aspects of the transcendental standpoint.

Kant's contrast between the maxims of nature and the principles that govern transcendental morality, as well as his insistence on the point that, suicide involving a rational contradiction, it cannot be freely chosen by the agent, are indicative of the two senses of freedom that transcendental 
idealism involves. They are formal freedom and substantive or transcendental freedom. Rational suicide would be free in the formal sense as long as it is an act that far from being determined by animal drives, it results from the fact that the subject determines himself to follow a certain urge, thus making himself minimally independent of it. However, such act would be conditional, and so, it could not be chosen from the perspective of an agent who instead of actively pursuing his natural ends in the process of making a decision, acts motivated by moral, transcendental ends. Thus, suicide would be a free act without being an act that expresses substantive freedom.

Within the Kantian tradition, the above distinction is expressed in the search of norms such that, in the case of conflict, would ever trump any other purpose. Those guiding principles would produce such firm conviction in the agent that - according to the words of Fichte - he "accepts the risk of not being able to alter either his manner of acting or the principles in according with which he is acting in this manner" (Fichte 2005, p. 160).

Notice, on the one hand, how Fichte's test of irrevocability is not unlike the psychological test that Nietzsche offers with the thoughtexperiment of the Eternal Recurrence, as it appears in section 341 of The Gay Science (Nietzsche 2001, p. 194). Such thought tests the relation between I and world in terms of the ultimate value and meaning of the world, and does so in almost the same words that Wittgenstein uses to formulate the problem - as the question of how one can be in agreement with the world in spite of its misery (NB, p. 81). Would one say "yes" to the world as a whole with all its horror and torment? Would not reveal such affirmative attitude that one invests any happening with the sancticy of eternal law?

Notice, on the other hand, that because the potential suicide would have revoked his act if his circumstances and conditions had been otherwise, his action does not pass the test of unconditionality, failing thus short of the unity between the agent and his actions that is the mark both of genuine freedom and of the "agreement with the world" (NB, p. 75) that, according to Wittgenstein, is the mark of a happy life. 
Suffice it to say that the preceding considerations are instrumental for solving several problems. They help, first, to see why suicide can be grounded in a voluntary, conscious resolution on the part of the agent without being free in the full sense of transcendental freedom. They also alleviate some of the sense of contradiction that Wittgenstein's remarks create in the reader. Recall, in this regard, that Wittgenstein says that one cannot will one's own destruction and seems to imply that because suicide is a rushing of one's defences, it is neither moral nor immoral.

My first point is that it is coherent to insist upon the fact that suicide consists in the subject's yielding to natural inertia while claiming that this act is not - as involuntary happenings are- unfree, and so, that it is not beyond the pale of ethical evaluation. The agent can voluntarily opt for rejecting transcendental freedom. A point that Wittgenstein apparently makes when attributing to his own baseness the suicidal condition into which he has fallen ${ }^{8}$.

My second point is that, following the lead of Kant and Schopenhauer, it is to the transcendental I - and not to the phenomenal ego whose action is formally free - to which Wittgenstein refers when claiming that it cannot will suicide. From the transcendental stand point, willing ceases, and with willing the investment in life which motivates suicide ceases too. This is also why Jacquette's suggestion of the philosophical suicide who - as a good disciple of Schopenhauer - decides to leave the phenomenal world at the prime of his life, is anything but Schopenhauerian. The transcendental position annuls suicide's conditions of possibility. It is only from the perspective of the individual that suicide is feasible. And from that perspective, however rational the decision appears to be, it would always be motivated by the will to life, being thus transcendentally unfree and immoral.

But, what about the doctrine of the illusory nature of the phenomenal world? How can transcendental idealism, which is committed

8 This is the only option fully consistent with Wittgenstein's conception of life as a task (Engelmann 1967, p. 79) and with the way in which he applied to his life the seriousness demanded by the moral duty of personal improvement. See, for example, what Malcolm says on this topic in Malcolm 1993, p. 10. 
to such doctrine, coherently bestow on a particular phenomenal deed a metaphysical significance?

This problem can be easily mitigated by paying attention to the fact that, for Schopenhauer, it is only from the perspective of the empirical ego that life appears as an illusion deprived of direction and meaning (Schopenhauer 1974, p. 270). From a higher point of view, however, phenomena are external manifestations of the inner reality and, as such, are imbued with a metaphysical sense.

The point is that, as an empirical ego, the suicide condemns himself to a view from which the world appears as a phantasmagoria of aimless pains, disconnected events and meaningless existences that pass from nothingness into nothingness. The world of the happy is different, indeed, from the world of the unhappy (NB, p. 78). The world of the latter is "a foolish piece of self-torture" (Schopenhauer 2006, p. 55) that results from the ethical position that he chooses to adopt. In this sense, how the world appears to the self depends upon what kind of moral standpoint or ethical attitude the self takes towards the world. The empirical perspective of the willing ego is not only objectively wrong, but also ethically defective.

This is why, in my view, when asking himself whether suicide possesses ethical significance, Wittgenstein is not adopting a kind of neutral position from which to evaluate two views that are on a par. There is just no argument that could be reconstructed outside the context of those particular ethical/metaphysical perspectives, as there is no theoretical starting point from which to assess and compare the world as it appears to the empirical ego and the world as seen by the transcendental I. Note, besides, that the question is not whether suicide belongs to ethics. What Wittgenstein faces is, on the contrary, the wholesale confrontation between the nihilistic and the metaphysical worldviews.

Let me be clear, however, on one important point. Wittgenstein's way of setting the stage does not imply radical relativism. That there is no initial basis for evaluating both positions it only means that they must be assessed by working out the results of the two mutually excluding perspectives. And it seems clear that there is a glaring asymmetry between them: while the empirical standpoint falls short of 
accommodating the metaphysical and ethical aspects of self and world, the metaphysical perspective makes sense of itself and of the world of appearances which sustains. Following a long tradition that goes back to Fichte, Wittgenstein institutes a measure that is both theoretical and practical. The world of the suicide is ethically and metaphysically a senseless world. A false view of the world is the sign of a false life.

Moreover, one could even plausibly claim that, for Wittgenstein, the despairing picture of the world to which the empirical ego is committed is the immediate punishment of its ethical failure. As an intriguing passage from the Notebooks in which Wittgenstein closely paraphrases Schopenhauer's doctrine of eternal justice (Schopenhauer 2010, p. 377384) suggests, there must be "a kind of ethical reward and of ethical punishment" of actions for the seriousness of life being even possible, though with the proviso that those consequences "cannot be events" and that they "must be involved in the action itself" (NB, p. 78). A directionless world is thus the reverse side of a fallen Will -its involved punishment.

However, it is not only how the world appears to the self that depends upon one's attitude to the world. It is also how the world is in itself that depends upon how the self confronts the world. The meaningless or meaningful nature of the world hangs, therefore, on whether the ego fails or not to overcome itself. This is the core of Schopenhauer's "single thought". Schopenhauer is most emphatic on the point that the meaning of the world lies in the acquisition of the transcendental perspective. Put in other words, the world becomes meaningful once the I stands outside and in front of the world as a whole so that through the I the Will measures itself and places itself on the scales. The self-abolition of the Will follows from this act of self-cognition.

The "single thought" is tersely expressed in a note that as early as in 1817 Schopenhauer wrote'. It says: "My entire philosophy can be summarized in the one expression: the world is the self-knowledge of the Will" (Schopenhauer 1988, p. 512). Importantly, an extended version of this thought is provided by Schopenhauer within the context of his discussion on suicide. There he writes as follows: "Nature leads

9 It was thanks to the effort and philosophical accuracy of John E. Atwell that the overwhelming importance of this note has been universally acknowledged within Schopenhauer's scholarship. See Atwell 1995, p. 18-31. 
the will to the light, because it is only in the light that it can find its redemption" (Schopenhauer 2010, p. 428).

The main point of the text is tolerably clear. Instead of being the work of utter chance and a heap of disconnected events related by mere succession, the objective world is the means through which the Will blindly pursues its aims, first, of crystalizing itself as an object capable of being known and assessed, and, second, of coming to produce the surplus of cognitive equipment required for the reflectiveness and independence from prudential considerations of the faculty of reason through which the Will can come to be aware of itself.

It is thus as if the world would be pressing towards the I as the measurer of the world so that through the I the world at last would hold up before itself a mirror. Through its reflection in the tormented world, the Will annuls itself and the self undergoes a conversion that is also the complete elimination of the empirical ego. Anhedonia - the cessation of willing; the pacification of the self; the suspension of that interest in life from which the dread of death springs - ensues. Importantly, the world acquires meaning by the very fact that the subject of will stands in front of the world as its measurer, so that by fulfilling the ends of nature the self does not leave the world unfulfilled. The meaning of the world is thus its coming to acquire meaning for the subject of will, so that by being seen through the I as significant it really becomes significant.

Suicide is thus the elementary sin - the sin that irrevocably stabs reality at its core. How could it be otherwise, when by that act the world is plunged into nothingness and its ends are frustrated?

It is Schopenhauer's "single thought" which reveals the meaning of Wittgenstein's oracular words on the nature of suicide.

\section{Asceticism and the Affirmation of the World}

Doubtless, the same teleological conception that Schopenhauer's "single thought" expresses is at work in some of the most remarkable notions of the Notebooks. 
Wittgenstein conceives the "metaphysical subject" (NB, p. 82) that "can and must" be mentioned "in a non-psychological sense in philosophy" (NB, p. 80) in terms of having "to judge the world, to measure things" (NB, p. 82) - terms that point to a transcendental standpoint from which the solution to the problem of the meaning of the world can "be seen in the disappearance of this problem" (NB, p. 74). Wittgenstein describes the happy man as one who "is fulfilling the purpose of existence" and who, because of that, "no longer needs to have any (empirical) purpose" (NB, p. 73) - thus connecting objective teleology and ethical redemption. He also says that "if the Will did not exist, neither would there be (a) centre of the world" (NB, p. 80); as he is most emphatic on the point that because the I is at the same time the bearer of the world and the bearer of ethics, a world which is not sustained by the Will - one without ethics - "in some sense (...) seems impossible" (NB, p. 77). More importantly, Wittgenstein also conceives redemption in terms of cognition (NB, p. 81) - so that the metaphysical, epistemic, and ethical aspects of reality converge upon the extensionless point where Idealism collapses into pure Realism.

However, there is an important juncture at which Wittgenstein takes leave of Schopenhauer's views - that of the ultimate rejection of the world that for Schopenhauer is the inevitable result of transcendental cognition. Note, however, that this crucial divergence might plausibly be seen not so much as a complete departure from Schopenhauer as the correct way of capturing Schopenhauer's insight that the world becomes meaningful through the I from which it is seen as meaningful, that is, from the right perspective that sees the world as right.

This would be an improvement on Schopenhauer along Schopenhauer's lines - one that alleviates the tension between Schopenhauer's nihilism and his transcendentalism. After all, how could one reject the world without also rejecting that the world has meaning?

Schopenhauer must respond to this doubt by observing that the purpose of the world lies in its cognitive self-annihilation. But this answer in some sense seems self-refuting. From the standpoint of the radical decision on whether to affirm or to reject the world as a whole, there is only one choice to be made that does not annul the very 
conditions of possibility for the existence and meaningfulness of any choice - and that choice is on the affirmative. By choosing "no", the Schopenhauerian nihilist would deprive himself of the very means that make the radical decision possible at all. He would have to agree with the world in order not to agree with it, to will the world with the purpose of not to will the world. His condition would be, therefore, as paradoxical as the situation of the radical Pyrrhonian who cannot suggest that our rational faculty is intrinsically defective without depriving the reasons that he raises for that conclusion of their rational standing. Again, and as in Kant's diagnosis of the contradictory nature of the potential suicide, the means-end structure on the basis of which the Schopenhauerian reasoner proceeds is undermined by his rejection of the world. Instead of being the tranquiliser of the Will, such rejection would exacerbate the anguish of the self, which is torn apart between nihilistic negation and the unconditional reconciliation of I and world. This is why Wittgenstein identifies a good conscience with a happy life, and why he defines a happy life as a life "in agreement with the world" (NB, p. 75). This is also why Wittgenstein conceives the solution of the problem of the meaning of life in terms of an agreement between "two godheads" (NB, p. 74), that is, between "my independent I" (NB, p. 74) and an alien Will that he identifies with God, fate, the world and "how things stand" (NB, p. 79).

The main divergence between Schopenhauer and Wittgenstein lies, therefore, in that while the former sees the pacification of the Will (a spurious pacification, as we have seen) as the indirect result of cognition -indirect because it comes from the turning of the Will as it confronts all its horror-, for Wittgenstein pacification and cognition are identical. Note, in this regard, that while on Schopenhauer's view the misery of the world acts as a revulsive of the Will, and so, as an objection to the world, Wittgenstein raises the question of meaning in spite of the misery of the world. His problem is how to make sense of the horrors of existence and come to accept them. Cognition is not thus the recognition of horror, but the recognition of a sense in such horror $-\mathrm{a}$ sense that without cheap romanticism, transforms the whole relation of the subject towards the world. Aware of being the light of the world to 
which the world presses, the transcendental I sheds light on the world and, in doing so, redeems itself as well as the world. This is, of course, the mystical perspective. But it also appears to be the proper means for putting an end to the inroads of science into metaphysics, so as to awake a pressing need for metaphysics and to make the unutterable manifest - not in one's acts, but in one's mode of acting. That those are the constant ends of Wittgenstein's practice of philosophy seems, at the very least, highly plausible.

Let me return, however, to the connection between the affirmative attitude that springs from the transcendental perspective and the ascetic life of one "who is content" (NB, p. 73). Since willing is the sign of a discomfort that express itself as one's attempt to affect the world so that it would comply with one's will, there is a clear sense in which a happy life and a life of immoderate willing are incompatible. However, Wittgenstein is not thinking about the mere moderation of willing. His thought is expressed in more drastic words; words that describe the life of the happy as one in which empirical purposes are no longer needed and one "can renounce the amenities of the world" (NB, p. 81). How can the affirmation of life and a life of renunciation be compatible? After all, is not extreme asceticism the clearest sign of a devaluing of the world?

As was suggested before, by seeing the world as right the transcendental subject invests in any happening whatsoever meaning. But this means that it is precisely because any event is invested with value that one can be confident independently of what happens in the world and what externally happens to one. One does not need to project one's desires into life to confer value on life. Value takes care of itself. The ethical self-overcoming makes then the I independent of the world as well as in agreement with it; its result is quietism and maybe, in certain sense of the word, fatalism. The whole position is, however, coherent: asceticism is the mode of acting through which redemption is manifested. It is no surprise that for the pacified self "the amenities of the world are so many graces of fate" (NB, p. 81), and that Wittgenstein had described the ethical life as that in which one follows the Will of God (NB, p. 75). Beatitude is the agreement of the indwelling God of 
the self and the Will of God; it is a condition of the person such that one acknowledges the events of the world as one's own Will.

Wittgenstein's reflections on the ascetic life contribute to confer new meanings on ethical practices that naturalism thought to have undermined, and so, to fix a rigid line of demarcation between the value that the ascetic ideal possesses in itself and the dogmatic interpretations on which it was usually grounded. Naturalistic philosophers are prone to think that they have undermined asceticism by undermining religious formulas. Wittgenstein corrects this error and, in doing so, presents a purified version of ethical and religious experience. To my mind, Wittgenstein and Nietzsche are not in disagreement even on the thorny question of the value of the ascetic ideal. As I see Nietzsche's critical investigation on asceticism as expressed in On the Genealogy of Morality, its objective is not so much the demise of the ascetic ideal as its reinterpretation on much firmer grounds. Nietzsche objects to the dogmatic appropriation of such ideal, but not to the self-overcoming that such form of life might easily express.

There is another possible interesting connection between Wittgenstein and Nietzsche in regards to the enigmatic and symbolic figure of Christ as it is described in The Anti-Christ. There is some plausibility in the view that Nietzsche's characterization of the redeemer as offering "a new practice" (Nietzsche 1985, p. 145) - and not a doctrine-, and as an example of an inner salvation where the eternal lies in the fixed present - and not in a future condition of rewards and punishments - might be the model on which Wittgenstein's reflections - as a new imitation of Christ - would be based. At any rate, it is clear that Wittgenstein's conception of the Christian religion is empty of theological doctrines, and that he saw it in terms of moral responsibility, inner redemption, conscience, guilt and despair. As he wrote:

The Christian religion is only for one who needs infinite help, therefore only for one who feels an infinite need. The whole planet cannot be in greater anguish than a single soul. The Christian faith - as I view it - is the refuge in this ultimate anguish. (CV, p. 52) 
It would be interesting to elucidate to what extent Wittgenstein's transcendental position is constant throughout the whole of his philosophical production, and whether the purpose of making the unutterable manifest is the leading thread that unifies his work and that sheds light on the meaning of his various investigations. That this further project is far from implausible it is apparently supported - to mention only four examples taken from different areas of philosophical research - by Wittgenstein's emphasis on conceiving the relation between will and action in terms of manifestation, by his description of our relation to persons as grounded on attitudes - not in opinions-, by his thought that difficulties in philosophy arise from a resistance of the Will that has to be overcome (BT 2005, p. 301), and by his characterisation of our relation to hinges as a proto-phenomenon.

Fundamental facts cannot be captured by empirical propositions. This point makes it impossible to place Wittgenstein's philosophy within the empiricist tradition. His philosophy must be relocated within a transcendental framework that Wittgenstein inherited from Kant via Schopenhauer's system.

Let us finish with a question that Wittgenstein raised to himself: "Then can there be a world that is neither happy nor unhappy?" (NB, p. 78)

From a Wittgensteinian perspective, the right answer is neither "yes" nor "no". Such "world" would not even be a world.

\section{References}

ATWELL, J. E. Schopenhauer on the Character of the World. Berkeley; Los Angeles: University of California Press, 1995.

ENGELMANN, P. Letters from Ludwig Wittgenstein With a Memoir. Oxford: Blackwell, 1967.

FICHTE, J. G. The System of Ethics. Cambridge: Cambridge University Press, 2005. 
GLOCK, H.-J. Schopenhauer and Wittgenstein: Representation as Language and Will. In: JANAWAY, C. The Cambridge Companion to Schopenhauer. Cambridge: Cambridge University Press, 1999. p. 422-458.

GÓMEZ-ALONSO, M. Wittgenstein on the Will and Voluntary Action. In: PADILLA GÁLVEZ, J. Action, Decision-Making and Forms of Life. Berlin; Boston: De Gruyter, 2016. p. 77-108.

JACQUETTE, D. Schopenhauer on Death. In: JANAWAY, C. The Cambridge Companion to Schopenhauer. Cambridge: Cambridge University Press, 1999. p. 293-317.

JACQUETTE, D. The Philosophy of Schopenhauer. Chesham: Acumen, 2005.

JANAWAY, C. Self and World in Schopenhauer's Philosophy. Oxford: Clarendon Press, 1989.

KANT, I. Groundwork of the Metaphysics of Morals. Cambridge: Cambridge University Press, 1998.

MALCOLM, N. Wittgenstein: A Religious Point of View? London: Routledge, 1993.

MORRIS ENGEL, S. Schopenhauer's Impact on Wittgenstein. Journal of the History of Philosophy, v. 7, n. 3, 1969, p. 285-302.

NIETZSCHE, F. Twilight of the Idols and The Anti-Christ. Harmondsworth: Penguin, 1985.

NIETZSCHE, F. The Gay Science. Cambridge: Cambridge University Press, 2001.

SCHOPENHAUER, A. Parerga and Paralipomena. Short Philosophical Essays. Volume Two. Oxford: Clarendon Press, 1974.

SCHOPENHAUER, A. Manuscript Remains. Volume I. Oxford: Berg Publishing, 1988.

SCHOPENHAUER, A. Prize Essay on the Freedom of the Will. Cambridge: Cambridge University Press, 2006.

SCHOPENHAUER, A. The Two Fundamental Problems of Ethics. Cambridge: Cambridge University Press, 2009.

SCHOPENHAUER, A. The World as Will and Representation. Cambridge: Cambridge University Press, 2010. v. 1. 
WITTGENSTEIN, L. Notebooks 1914-1916. Chicago: The University of Chicago Press, 1984.

WITTGENSTEIN, L. A Lecture on Ethics. In: WITTGENSTEIN, L. Philosophical Occasions 1912-1951. Indianapolis; Cambridge: Hackett, 1993. p. 37-44.

WITTGENSTEIN, L. The Big Typescript: TS 213. Oxford: Blackwell, 2005. WITTGENSTEIN, L. Culture and Value. Oxford: Blackwell, 2006.

Recebido: 29/12/2017

Received: 12/29/2017

Aprovado: 09/02/2018

Approved: 02/09/2018 